The AAPS Journal 2005; 7 (1) Article 1 (http://www.aapsj.org).

\title{
Characterization of the Human MDR1 Gene
}

Submitted: May 27, 2004; Accepted: August 26, 2004; Published: February 11, 2005.

\author{
Miklos Bodor, ${ }^{1}$ Edward J. Kelly, ${ }^{1}$ and Rodney J. Ho ${ }^{1}$ \\ ${ }^{1}$ Department of Pharmaceutics, University of Washington, Seattle, Washington
}

\begin{abstract}
P-glycoprotein (Pgp), an ATP-dependent efflux transporter that protects the body from environmental toxins and xenobiotics, is encoded by the human MDRl gene. Human MDRl is located on chromosomal region 7q21. Although several different single nucleotide polymorphisms were shown to influence Pgp expression and activity, the reported length of the MDRI gene in Genbank and other databases continues to evolve and varies between 6.3 kilobases $(\mathrm{kb})$ and $210 \mathrm{~kb}$. With DNA derived from human cell lines and tissues, we have characterized the MDRl genomic sequence to be $209 \mathrm{~kb}$.
\end{abstract}

KEYWORDS: MDR1 gene, P-glycoprotein, gene arrangements.

\section{INTRODUCTION}

P-glycoprotein (Pgp), a member of the ATP binding cassette family of membrane transporters, is encoded by the human multidrug-resistance (MDR1, $A B C B 1)$ gene..$^{1,2}$ This integral membrane protein functions as an energy-dependent drug efflux pump and reduces the intracellular concentrations of a wide range of drugs and xenobiotics. Comprehensive reviews were published recently on this topic. ${ }^{3,4}$ Pgp exhibits wide substrate specificity for structurally different drugs and, consequently, mediates drug resistance to a variety of drugs, including Vinca alkaloids, anthracyclines, epipodophyllotoxins, taxols, actinomycin D, cardiac glycosides, immunosuppressive agents, glucocorticoids, and anti-HIV protease inhibitors..$^{5-7}$ Since many drugs are substrates of Pgp, its degree of expression and functionality directly affects the therapeutic effectiveness of these agents. In particular, resistance to chemotherapy has become a major obstacle in anticancer treatment, but the exact regulatory mechanism of the protein expression remains elusive. One of the possible regulatory sequences was identified in the promoter region. ${ }^{8}$ Other studies found random chromosomal rearrangements causing hybrid MDR1 messages and consequent activation of Pgp expression. ${ }^{9}$

The MDRl gene is located on the long arm of chromosome 7 and consists of a core promoter region and 29 exons. The

Corresponding Author: Rodney J. Ho, Department of

Pharmaceutics, University of Washington, P.O. Box 357610, Seattle, Washington 98195-7610. Tel: (206) 543-9434. Fax: (206) 543-3204. Email: rodneyho@u.washington.edu. total gene length was established and reported in 1987 to be at least 70 kilobases $(\mathrm{kb}),{ }^{10}$ and later in 1990, using multidrug-resistant $\mathrm{KB}-\mathrm{V} 1$ cells, the $M D R 1$ gene size was estimated to reach more than $100 \mathrm{~kb} .{ }^{11}$ Although widely investigated, the exact genomic size has remained uncertain for the past 16 years, with several differing entries in the Genbank database. The online databases list MDRl gene length to be between $120 \mathrm{~kb}$ (http://www.infobiogen.fr) and $210 \mathrm{~kb}$ (www.ncbi.nlm.nih.gov/IEB/Research/Acembly). ${ }^{12,13}$ The NCBI database (http://www.ncbi.nlm.nih.gov) outlines a 209-kb MDRl genome. ${ }^{13}$ Another source (www.ensembl. org) enumerates 29 exons within the gene, while Aceview (www.ncbi.nih.gov/IEB/Research/Acembly) computational analysis predicts 29 exons with 18 alternative exons and 32 confirmed introns, 10 of which are alternative. ${ }^{14}$ In addition, alignment of the MDRI mRNA with the DNA sequence deposited at the Chromosome 7 Sequencing Project (www.chr7.org) reveals 29 discrete matches suggesting that there are $29 M D R 1$ exons. While several changes were made in the databank during the past decade, the latest revision available online still lists the total length of MDR1 as $209 \mathrm{~kb}$ ( $\underline{\mathbf{N T 0 0 7 9 3 3}})$ and 6326 base pairs (bp) ( $\underline{\mathbf{A H 0 0 2 8 7 5}}$, accessed September 2003). The MDR1 mRNA consists of 4872 bp (NM000927). The reported gene structure is mainly based on very limited cell specimens. Comparative and validation studies with different human tissues or cells are not yet available in the literature.

The aim of this study was to evaluate and validate the overall length of the human MDRl gene so that detailed gene structure function studies can be performed with confidence. This knowledge can then serve as a reference when investigating mechanisms of drug resistance due to variation in the $M D R 1$ gene.

\section{Materials AND Methods}

Human liver samples harvested from brain-dead donors that had been rejected for transplantation, mostly because of a high degree of fatty infiltration, were obtained from the University of Washington, Seattle, WA, Solid Organ Transplant Program. The human lymphocytes were isolated from blood obtained from the Blood Bank at the University of Washington. Human cell lines (Messa Dox [ovarian carcinoma], $\mathrm{CaCo} 2$ [colon carcinoma], and UW 228 [primary human medulloblastoma cells]) were purchased from American Type Culture Collection (ATCC, Manassas, VA). Genomic DNA was extracted and purified from the samples 
The AAPS Journal 2005; 7 (1) Article 1 (http://www.aapsj.org).

Table 1. Experimental Design of PCR and Southern Blot Analysis, and the Expected Products According to the 2 Reference Sequences of the MDRl Gene*

\begin{tabular}{|c|c|c|c|c|}
\hline \multicolumn{3}{|c|}{ Analytical Method } & \multirow{2}{*}{\multicolumn{2}{|c|}{$\begin{array}{l}\text { Expected Product and Fragment } \\
\text { According to the Respective Size of } M D R 1\end{array}$}} \\
\hline \multicolumn{3}{|c|}{ PCR Analysis } & & \\
\hline Primers & \multicolumn{2}{|c|}{ Primer Sequence $5^{\prime}$ to $3^{\prime}$} & $\begin{array}{c}6.3 \text { kb MDR1 } \\
\text { Length (AH_002875) }\end{array}$ & $\begin{array}{c}209 \text { kb MDR1 } \\
\text { Length (NT_007933) }\end{array}$ \\
\hline $\begin{array}{l}\text { F19 } \\
\text { R19 }\end{array}$ & \multicolumn{2}{|c|}{$\begin{array}{l}\text { CCCATCATTGCAATAGCAGG } \\
\text { GTTCAAACTTCTGCTCCTGA }\end{array}$} & $190 \mathrm{bp}$ & 10573 bp \\
\hline $\begin{array}{l}\text { F27 } \\
\text { R27 }\end{array}$ & \multicolumn{2}{|c|}{$\begin{array}{l}\text { TCCAGTTTCCTTTTGGAGGA } \\
\text { TGTCGTTTTGTTTCAGGATCA }\end{array}$} & 214 bp & $2835 \mathrm{bp}$ \\
\hline $\begin{array}{l}\text { F28 } \\
\text { R28 }\end{array}$ & \multicolumn{2}{|c|}{$\begin{array}{l}\text { TGGTTTCGATGATGGAGTCA } \\
\text { AGCTTTCTGTCTTGGGCTTG }\end{array}$} & $285 \mathrm{bp}$ & $1112 \mathrm{bp}$ \\
\hline \multicolumn{3}{|c|}{ Southern Blot Analysis } & & \\
\hline $\begin{array}{l}\text { Restriction Enzyme } \\
\text { Pairs } \\
\end{array}$ & $\begin{array}{l}\text { Radiolabeled } \\
\text { Probe }\end{array}$ & Target Regions & & \\
\hline BamHI/PacI & P1 & Introns 8 and 9-14 & $6 \mathrm{~kb}$ & $7 \mathrm{~kb}$ and $9 \mathrm{~kb}$ \\
\hline BamHI/KpnI & $\mathbf{P 2}$ & Introns $15-19$ and $20-21$ & $5 \mathrm{~kb}$ & $7 \mathrm{~kb}$ and $14 \mathrm{~kb}$ \\
\hline BamHI/PacI & P3 & Introns 21 and 15-20 & $6 \mathrm{~kb}$ & $11 \mathrm{~kb}$ and $16 \mathrm{~kb}$ \\
\hline
\end{tabular}

*PCR indicates polymerase chain reaction; kb, kilobase; and bp, base pair.

using the Puregene DNA Isolation Kit (Gentra Systems Inc, Minneapolis, MN). Primers were designed with an online primer design software program (Primer 3) and synthesized by Invitrogen Co (Carlsbad, CA). The list of primers and their target MDR1 products are listed in Table 1. In the case of primer sets F27-R27 and F28-R28, the reaction mixtures (50 $\mu \mathrm{L}$ total volume) contained $100 \mathrm{ng}$ genomic DNA, 200 $\mu \mathrm{M}$ each dNTP, $3.0 \mathrm{mmol} \mathrm{MgCl}_{2}, 4.0$ units of Taq polymerase (Promega, Madison, WI), $10 \mathrm{mmol}$ of primers, 5.0 $\mu \mathrm{L}$ Thermo DNA Poly 10X reaction buffer (Promega, Madison, WI), and nuclease-free $\mathrm{H}_{2} \mathrm{O}$. Thermocycling was conducted in a PerkinElmer DNA Thermocycler (model 2400, Foster City, CA) with the following profile: initial denaturation at $94^{\circ} \mathrm{C}$ for 3 minutes immediately followed by 35 cycles of $94^{\circ} \mathrm{C}$ for 30 seconds, $55^{\circ} \mathrm{C}$ for 30 seconds, and $72^{\circ} \mathrm{C}$ for 1 minute. In the case of the F19-R19 primer set, designed to produce over $10 \mathrm{~kb}$ of product, the same amount of genomic DNA was amplified in 2 units of rTth DNA polymerase (PerkinElmer), containing $10 \mathrm{mmol}$ of primers, 200 $\mu$ mol each dNTP, $15 \mu \mathrm{L} 3.3 \mathrm{X}$ XL buffer, $2.4 \mu \mathrm{L} \mathrm{Mg}(\mathrm{OAc})_{2}$ solution, and nuclease-free $\mathrm{H}_{2} \mathrm{O}$. The long-range polymerase chain reaction (PCR) was conducted as follows: initial denaturation at $94^{\circ} \mathrm{C}$ for 1 minute followed by 16 cycles of $94^{\circ} \mathrm{C}$ for 15 seconds, $58^{\circ} \mathrm{C}$ for 30 seconds, and $68^{\circ} \mathrm{C}$ for $10 \mathrm{~min}$ utes. This was immediately followed by 12 cycles of $94^{\circ} \mathrm{C}$ for 15 seconds, $58^{\circ} \mathrm{C}$ for 30 seconds, and $68^{\circ} \mathrm{C}$ for $10 \mathrm{~min}$ utes with an incremental increase of 15 seconds per cycle. Products were visualized in a $2 \%$ agarose gel stained with ethidium bromide.

For the Southern Blot analysis, $10 \mu \mathrm{g}$ of genomic DNA was digested to completion with the restriction endonuclease pairs BamHI/PacI and BamHI/KpnI obtained from New England Biolabs (Beverly, MA). The DNA was electrophoresed on a $0.8 \%$ agarose gel, transferred to a nitrocellulose membrane, and hybridized with ${ }^{32} \mathrm{P}$-labeled probes prepared by random primed incorporation of $\alpha^{32} \mathrm{P}-\mathrm{dATP}$ by Klenow DNA polymerase (New England Biolabs). These probes were obtained by first generating 3 different MDR 1 cDNA regions using primer sets F7 (CTGCTGTCTGGGCAAAGATAC)-R7 (ACAGGTTCCTGACTCACCAC), F28-R29 (CGAGCCTGGTAGTCAATGCT), and F19-R19 (see Table 1 for sequence), designated as P1, $\mathrm{P} 2$, and P3, respectively (Figure 1). Probe P1 is labeled as target for introns 8 and 9 to 14; probe $\mathrm{P} 2$ is labeled as target for introns 15 to 19 and 20 to 21, and probe P3 is labeled as target for introns 21 and 15 to 20.

\section{RESULTS AND DISCUSSION}

We have chosen a critical region of the MDRl gene (spanning exons $8-21 ; 43 \mathrm{~kb}$ ), which would distinguish the 6.3- vs 209-kb version of MDRl gene for detailed analysis. To do so, we isolated DNA from liver samples, continuous cell lines expressing Pgp, and human lymphocytes. These DNA samples were analyzed with 3 regions of the MDRl gene and 3 different primer sets were used to amplify the respective gene sequences by PCR to distinguish the 2 versions of MDR1.

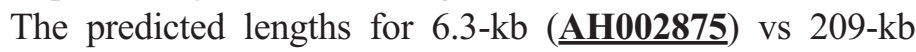
(T007933) MDRl gene amplicons are shown in Table 1. The sequences of the primer pairs F19-R19, F27-R27, and F28-R28 were designed to yield significant differences in the product sizes according to the 2 proposed gene lengths. The 


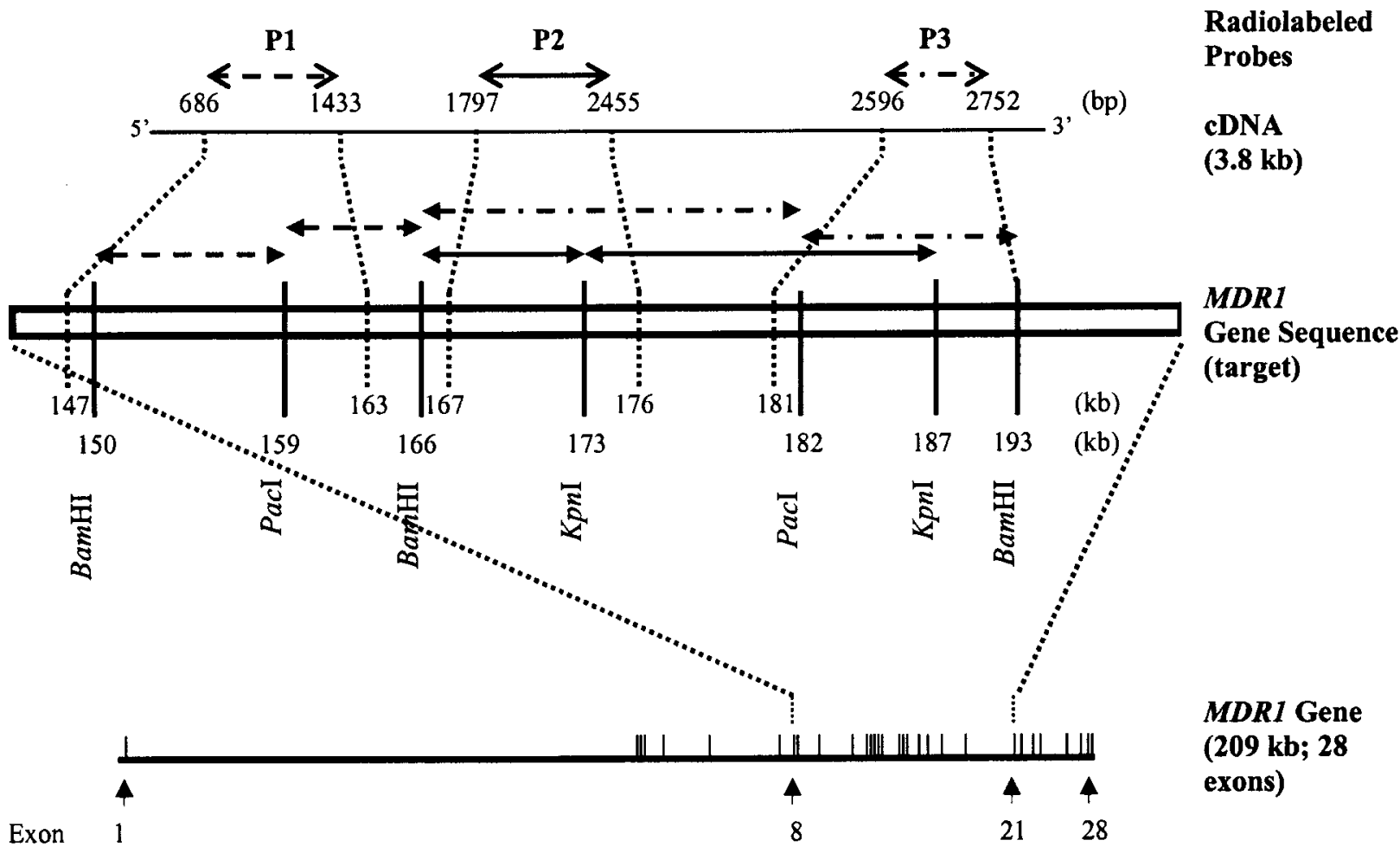

Figure 1. Schematic representation of restriction map based on the estimated 209-kb length and the radiolabeled cDNA fragments used as probes. The corresponding hybridization targets (arrows) are marked. Radiolabeled probes, P1, P2, and P3 were generated with F7R7, F28-R29, and F19-R19 primer sets (Table 1), respectively.

3 primer sets are designed to probe the sequences spanning introns 15, 17, and 21. Table 1 also lists the expected results of Southern Blot analysis for the 2 candidate sequences for MDR1. The schematics of restoration map of the 209-kb $M D R 1$ gene sequence (accession number $\underline{\mathbf{N T 0 0 7 9 3 3}}$ ) is presented in Figure 1.

With DNA isolated from 4 human livers, 3 human lymphocytes, and established cell lines-Messa Dox, $\mathrm{CaCo}$, and UW 228-we performed PCR with the 3 sets of primers listed in Table 1, and the results are shown in Figure 2. We were not able to detect any product in the reactions corresponding to the $6.3-\mathrm{kb} M D R 1$ candidate sequence. Instead, we found for all the liver tissues (2), lymphocytes (3), and cell lines (3), the PCR products corresponded to the length predicted with a 209-kb MDR1 sequence (T№07933). As shown in Figure 2, the products of F19/R19, F27/R27, and F28/R28 were $10.5,2.84$, and $1.1 \mathrm{~kb}$, respectively. The inability to detect products of short fragments was not due to PCR conditions, as the control MDRI cDNA derived from Messa Dox resulted in positives for all the reactions with the 3 sets of primers (Figure 2).

The PCR results were verified further with Southern Blot analysis to probe introns 8 to 21 (Figure 1). We found that the radiolabeled probes $\mathrm{P} 1-\mathrm{P} 3$ pointed to $209-\mathrm{kb}$ MDR1 sequence candidate. With BamHI/PacI and P1, we found 7 and $9 \mathrm{~kb}$; with BamHI/KpnI and P2, we found 7 and $14 \mathrm{~kb}$; and finally with $\mathrm{Bam} \mathrm{HI} / \mathrm{PacI}$ and P3, we found 11- and 16$\mathrm{kb}$ fragments (Table 1 and Figures 1 and 3). The bands correspond to the estimates shown in Table 1 for the more than 200-kb gene length. Again, there were no DNA bands corresponding to the length $(5$ and $6 \mathrm{~kb})$ of product predicted by the $6.3-\mathrm{kb}$ total gene size. Collectively, the above data strongly suggest the MDRl gene sequence is consistent with NT007933.

As the Genbank data are often based on the analysis of limited DNA specimens, we used several different human cell lines as well as lymphocyte and liver samples to investigate eventual differences between tissues and/or subjects regarding the MDR1 gene locus. Both sets of experiments confirm the length of the MDR1 gene being much longer than $6.3 \mathrm{~kb}$, and it is most likely $209 \mathrm{~kb}$ as indicated in the database (accession number NT007933). The results were consistent in the cases of different human liver tissue samples, several cell lines, and lymphocytes, showing that there is very little, if any, interindividual variation with respect to the gene length (Figures 2 and 3). The recent research interest to characterize differences in gene expression related to variation in drug response among individuals has begun to provide some clues to $M D R 1$ gene regulatory mechanisms. Discoveries of $M D R 1$ sequence variation in contig sequences have provided some clues. However, detailed studies of $M D R 1$ gene regulation require a validated $M D R 1$ sequence. Toward this end, we have provided data validating the $209-\mathrm{kb} M D R 1$ sequence. 


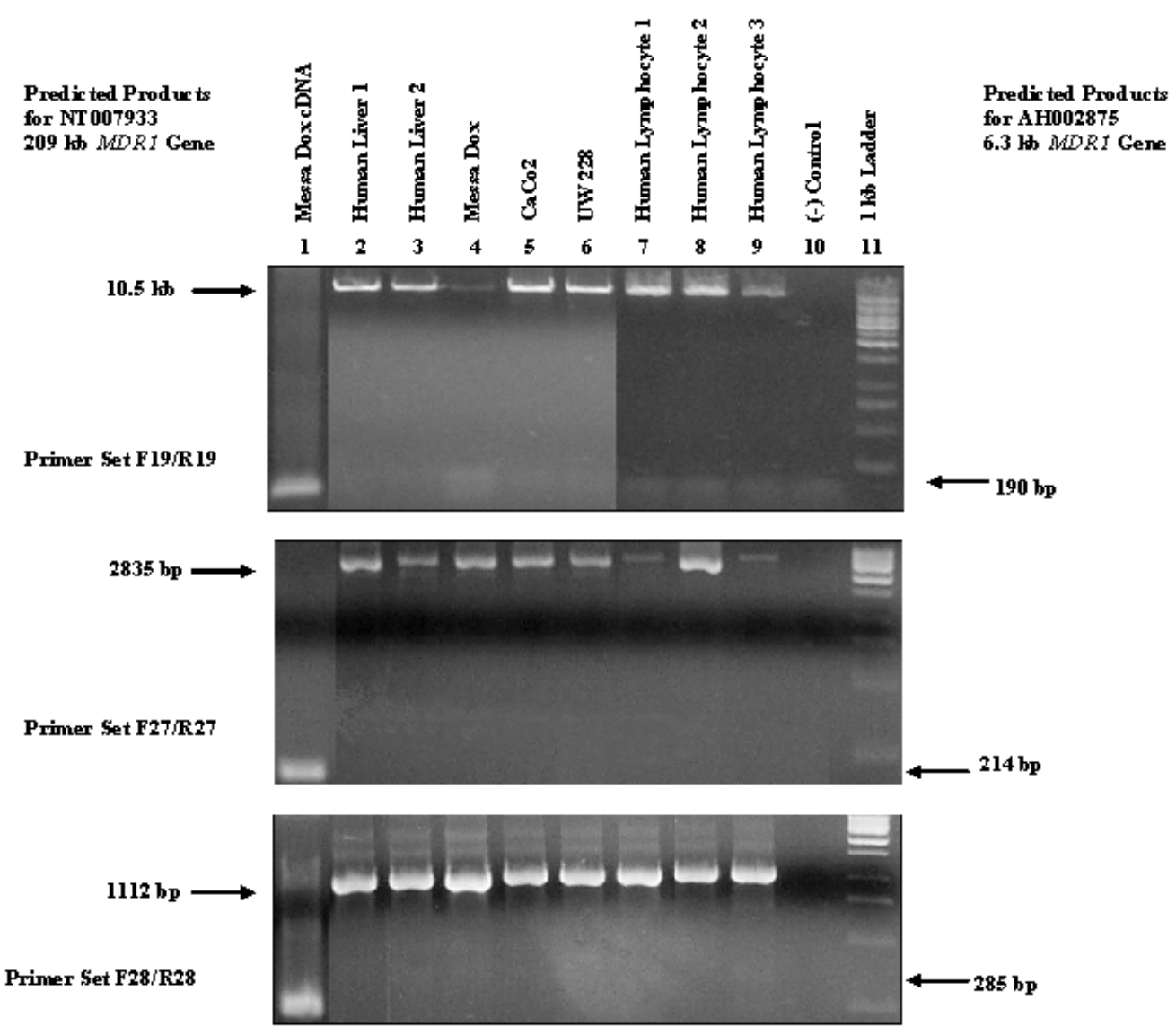

Figure 2. PCR analysis of the 3 MDR1 gene sequences using F19-R19, F27-R27, and F28-R28 primer sets (Table 1), respectively. Lane 1 is cDNA of Messa Dox cells; lanes 2 and 3 are 2 different liver samples; lanes 4, 5, and 6 are Messa Dox, Caco2, and UW 228 cell lines; and lanes 7,8, and 9 are 3 different lymphocyte samples. Lane 10 is a negative control in which no DNA was added, and lane 11 is a $1-\mathrm{kb}$ ladder. There were amplifications in all the samples according to the $209-\mathrm{kb}$ gene length, having sizes according to Table 1. There were no bands that showed up according to a 6.3-kb total MDR1 gene length. Results for Messa Dox cDNA were added to show reaction sensitivity for short fragments as well; the PCR products were $167 \mathrm{bp}, 171 \mathrm{bp}$, and $249 \mathrm{bp}$ for primer sets F19-R19, F27-R27, and F28-R28, respectively.

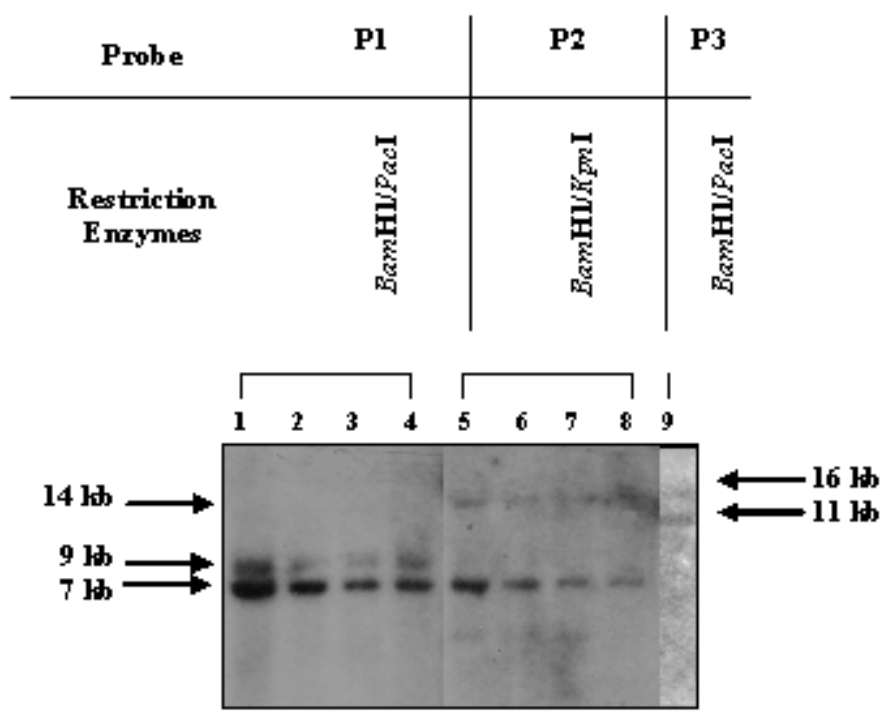

Figure 3. Southern Blot analysis of $M D R 1$ gene with DNA isolated from human livers. Genomic human liver DNA was subjected to BamHI/PacI (columns 1-4), BamHI/KpnI (columns 58), and BamHI/PacI (column 9) restrictions and P1, P2, and P3 radiolabeled probes, accordingly.
The results of our study confirming the size of the MDRI gene will be of great utility when extended to analyses of mechanisms of drug-induced resistance. In other words, knowledge of both intron-exon structure and overall gene length can be used to differentiate between aberrant mRNA splicing and gene deletions in multidrug resistance. In addition, there are several references in the literature regarding "mini-Pgp," 15,16 but there have been no molecular analyses to explain this phenomenon or its cause; our reference for $M D R 1$ gene structure will aid in these investigations.

In summary, data presented in this report have clarified and established that MDR1 gene length is likely to be $209 \mathrm{~kb}$.

\section{ACKNOWLEDGEMENTS}

Supported in part by NIH grants GM62883, AI52663, NS39178, AI31854, ES07033, and HL56548; and the University of Washington Center for DNA Sequencing and Gene Analysis. (This statement was communicated previously via email, September 14, 2004.) 


\section{The AAPS Journal 2005; 7 (1) Article 1 (http://www.aapsj.org).}

\section{REFERENCES}

1. Ueda K, Cornwell MM, Gottesman MM, et al. The mdrl gene, responsible for multidrug-resistance, codes for P-glycoprotein. Biochem Biophys Res Commun. 1986;141:956-962.

2. Borst P, Evers R, Kool M, Wijnholds J. A family of drug transporters: the multidrug resistance-associated proteins. J Natl Cancer Inst. 2000;92:1295-1302.

3. Sakaeda T, Nakamura T, Okumura K. Pharmacogenetics of MDR1 and its impact on the pharmacokinetics and pharmacodynamics of drugs.

Pharmacogenomics. 2003;4:397-410.

4. Woodahl EL, Ho RJ. The role of MDR1 genetic polymorphisms in interindividual variability in P-glycoprotein expression and function. Curr Drug Metab. 2004;5:11-19.

5. Gottesman MM, Pastan I. Biochemistry of multidrug resistance mediated by the multidrug transporter. Annu Rev Biochem. 1993;62:385-427.

6. Ueda K, Okamura N, Hirai M, et al. Human P-glycoprotein transports cortisol, aldosterone, and dexamethasone, but not progesterone. J Biol Chem. 1992;267:24248-24252.

7. Saeki T, Ueda K, Tanigawara Y, Hori R, Komano T. Human P-glycoprotein transports cyclosporin A and FK506. J Biol Chem. 1993;268:6077-6080.

8. Labialle S, Gayet L, Marthinet E, Rigal D, Baggetto LG.

Transcriptional regulation of the human MDR1 gene at the level of the inverted MED-1 promoter region. Ann N Y Acad Sci. 2002;973:468-471.
9. Mickley LA, Spengler BA, Knutsen TA, Biedler JL, Fojo T. Gene rearrangement: a novel mechanism for MDR-1 gene activation. J Clin Invest. 1997;99:1947-1957.

10. Ueda K, Clark DP, Chen CJ, Roninson IB, Gottesman MM, Pastan I. The human multidrug resistance (mdr1) gene. cDNA cloning and transcription initiation. J Biol Chem. 1987;262:505-508.

11. Chen CJ, Clark D, Ueda K, Pastan I, Gottesman MM, Roninson IB. Genomic organization of the human multidrug resistance (MDR1) gene and origin of P-glycoproteins. J Biol Chem. 1990;265:506-514.

12. INFOBIOGEN [database online]. Evry Cedex, France: Centre de Ressources INFOBIOGEN; 2004. Updated March 2004.

13. NCBI [database online]. Bethesda, MD: National Center for Biotechnology Information; 2004. Updated March 2004.

14. Project Ensembl [database online]. Hinxton, UK: The Wellcome Trust Sanger Institute; 2004. Updated March 2004.

15. Trambas C, Wang Z, Cianfriglia M, Woods G. Evidence that natural killer cells express mini P-glycoproteins but not classic $170 \mathrm{kDa}$ P-glycoprotein. Br J Haematol. 2001;114:177-184.

16. Kawai K, Kusano I, Ido M, Sakurai M, Shiraishi T, Yatani R. Identification of a P-glycoprotein-related protein (mini-P-glycoprotein) which is overexpressed in multidrug resistant cells. Biochem Biophys Res Commun. 1994;198:804-810. 